\title{
Isolation of papain-soluble collagen from the skin of snake-head
}

\section{fish (Channa striata)}

\section{Andi Rahmayanti Ramli ${ }^{1 *}$, Andi Rezky Annisa ${ }^{2}$, Nur Alim Bahmid ${ }^{3,4}$, and Muhammad Dalvi Mustafa $^{5}$}

${ }^{1}$ Department of Agriculture Technology, Faculty of Agriculture, Hasanuddin University, Indonesia

${ }^{2}$ Study Program of Aquatic Resources Management, Faculty of Marine and Fisheries, Hasanuddin University, Indonesia

${ }^{3}$ Agricultural Product Technology Department, Universitas Sulawesi Barat, Indonesia

${ }^{4}$ Food Quality and Design Group, Wageningen University and Research, Netherlands

${ }^{5}$ Study Program of Social Economic of Fisheries, Faculty of Marine and Fisheries, Hasanuddin University, Indonesia

\begin{abstract}
Snake-head fish (Channa striata) skin categorized a byproduct contains a higher concentration of collagen. The collagen can be extracted by using protease, which is known as Papain Soluble Collagen (PaSC). This study aimed to isolate the collagen from the snake-head fish skin using papain. The yield percentage and moisture content of PaSC in the skin was determined. Measurements using SDS-polyacrylamide gel electrophoresis (SDS-PAGE) and Fourier transform infrared spectroscopy (FTIR) were performed to characterize the PaSC and its functional groups. The results showed that the yields and moisture content of PaSC were $8.9 \%$ and $6.07 \%$, respectively. The PaSC characterized by two $\alpha$-chains appeared as collagen type I. Fourier transform infrared (FTIR) spectra of PaSC confirmed a triplehelical structure of collagen. The results indicated that snake-head fish skin could be used as potential resources of collagen and papain can be used as an alternative affordable enzyme.
\end{abstract}

\section{Article History}

Received September 11, 2020

Accepted December 29, 2020

Keyword

Collagen

Papain

Snake-head fish

\section{Introduction}

Bovine and pig are major sources of collagen. However, the collagen obtained from land animal become a main concern due to the outbreak of mad cow (1). Moreover, products contain the collagen sourced from pig are not permitted for consumption under Islamic law. Therefore, alternative sources of the collagen, e.g. aquatic animals, are essential to replace the bovine- and pig-source collagen (2).

Snake-head fish is one of the freshwater organisms, categorized as Channidae family. In Indonesia, amount of the snake-head fish being catched increased from 27.930 tonnes to 34.007 tonnes between 2009 and 2010 (3). The snake-head fish contains a high level of albumin, found in flesh of the fish (4). The flesh of the fish is dominantly consumed, while other parts of the fish, e.g. bones and skin, are wasted. Nonetheless, the skin contains a high concentration of collagen and can be, therefore, a potential source of the collagen.

The collagen extraction can be performed by using acid (5-7), enzyme (7-9), and water (10). The extraction using enzyme is more effective than the extraction using the water and acid due to a cross-linking in the collagen molecule. The enzymes that can be used for the collagen extraction are proteolytic enzymes (protease), such as pepsin, pancreatin 
and trypsin $(11,12)$. The pepsin obtained from porcine is known to be able to break the cross-linked molecule at telopeptide regions $(7,13,14)$. However, the health-concerns in the swine flu outbreaks and the acceptability for the muslim community need to be consider for the usage of porcin pepsin for consumption. A plant-origin protease, such as papain, could be a good alternative to extract the collagen from snake-head fish skin. Furthermore, the information regarding the papain-soluble collagen is limited.

Therefore, this study aims to isolate the collagen from the snake-head fish skin using a plant-sourced enzyme, papain. The results of the study give an insight into a new source of the collagen from the aquatic animals to replace the bovine- and pig-source collagen and its extraction method using an affordable and plant-sourced enzyme.

\section{Materials and Methods}

\subsection{Materials and Chemicals}

The snake-head fish used in the study was obtained from the local market. The chemicals, such as sodium chloride, acetic acid, ethanol, papain, tris (hydroxymethyl) aminomethane were purchased from Merck. The sodium hydroxide was purchased from Sigma Aldrich.

\subsection{Fish Skin Preparation}

The snake-head fish skin was separate from flesh, scales, fin, and spine. The skin was then cut into small pieces ( 2 in $4 \mathrm{~cm}$ ) and washed using clean water. The 2 -in- $4 \mathrm{~cm}$ cut skins were packed in plastic and stored at $-20^{\circ} \mathrm{C}$ until usage.

\subsection{Extraction of Papain Soluble Collagen (PaSC)}

The prepared fish skin was defatted using $50 \%$ ethanol solution with ratio of $1: 2(\mathrm{w} / \mathrm{v})$ for 60 mins at $\pm 7^{\circ} \mathrm{C}$. The skin was then washed using cold water until the $\mathrm{pH}$ reached neutral $\mathrm{pH}$. The defatted fish skin was mixed with $0.1 \mathrm{M} \mathrm{NaOH}$ at an alkali solution ratio of 1:10 $(\mathrm{w} / \mathrm{v})$ to remove non-collagenous components. The mixture was then stirred for 6 hours at $\pm 7^{\circ} \mathrm{C}$. Every two hours, the stirring was stopped to change the used alkali solution. Finally, the treated skin was washed using the cold water until the $\mathrm{pH}$ was neutral.

The pre-treated fish skin was soaked in $0.5 \mathrm{M}$ acetic acid with sample to solution ratio of $1: 15(\mathrm{w} / \mathrm{v})$ for 48 hours. The mixture was filtered using a cloth. The collagen extract was precipitated by adding $\mathrm{NaCl}$ until its final concentration was $2.6 \mathrm{M}$ in the presence of $0.05 \mathrm{M}$ Tris (hydroxymethyl) aminomethane. Afterwards, the pellet was dialysed using $0.1 \mathrm{M}$ acetic acid with ratio 1:10 (w/v) for 48 hours followed by dialysis in the same volume of distilled water for another 24 hours. The dialysate was freeze-dried, and this dialysate was referred as acid soluble collagen (ASC).

The insolubilized residue obtained after ASC extraction was subjected into PaSC extraction. The residue was soaked in $0.5 \mathrm{M}$ acetic acid with ratio $1: 5(\mathrm{w} / \mathrm{v})$ and papain (10.000 U/g residue) (EC 3.4.22.2; $30000 \mathrm{USP}-\mathrm{U} / \mathrm{mg}$; from papaya) was, afterwards, added. The mixture was stirred $\pm 7^{\circ} \mathrm{C}$ for 70 hours $(9,15)$. The collagen extract was precipitated by adding $\mathrm{NaCl}$ until its final concentration was $2.6 \mathrm{M}$ in the presence of $0.05 \mathrm{M}$ Tris (hydroxymethyl) aminomethane. The resultant precipitate was collected by centrifuge at $5000 \mathrm{rpm}$ for 60 mins. The pellet was mixed with $0.5 \mathrm{M}$ acetic acid with ratio $1: 2(\mathrm{v} / \mathrm{v})$. Afterward, it was dialysed using $0.1 \mathrm{M}$ acetic acid with ratio 1:10 (w/v) for 48 hours, 
followed by dialysis in the same volume of distilled water for another 24 hours. The dialysate was freeze dried and the freeze-dried dialysate was referred as papain soluble collagen (PaSC)

\subsection{Collagen yield analysis}

PaSC yield was calculated by dividing the amount of PaSC with the initial amount of wet weight fish skin then multiplied by $100 \%$.

\subsection{Moisture content analysis}

Moisture content of the PaSC was measured using oven-drying and weighing methods $(926.12,41.1 .02)$ by following AOAC

\subsection{SDS-polyacrylamide gel electrophoresis (SDS-PAGE)}

SDS-polyacrylamide gel electrophoresis (SDS-PAGE) is a technique to separate the protein based on their molecular weight (16). SDS-PAGE was performed using the method of Laemmli (17) with slight modifications. The non-freeze dried samples were mixed at a ratio of $4: 1(\mathrm{v} / \mathrm{v})$ with the sample buffer $(0.5 \mathrm{M}$ Tris (hydroxymethyl) aminomethane, 33\% SDS, $13 \%$ glycerol, and $3 \% \beta$-mercapto ethanol). The mixtures were added into the boiling water for 5 minutes. The samples were loaded onto polyacrylamide gels comprising of $7.5 \%$ of separation gel and $4 \%$ of stacking gel under control of the electrophoresis at a constant flow (70 volt/400 mA) for 2-3 hours using electrophoresis instruments (Bio-Rad Laboratories, Inc., Richmond, CA, USA). After electrophoresis, the gel was stained in staining solution (45\% methanol, $10 \%$ acetic acid, and $0.06 \%$ coomasie brilliant blue R-250) for an hour and then destained with $10 \%$ methanol and $10 \%$ acetic acid. High molecular weight markers were used to estimate the molecular weight of proteins.

\subsection{Fourier transform infrared (FTIR) spectroscopy}

Functional groups of PaSC were analyzed using Fourier transform infrared spectroscopy (FTIR) as described in the method of Yan et al. (18). Approximately $2 \mathrm{mg}$ of PaSC was mixed with $100 \mathrm{mg}$ of potassium bromide $(\mathrm{KBr})$. The mixture was analysed using FTIR and the infrared (IR) spectra was scanned at wave numbers $4000-500 \mathrm{~cm}^{-1}$. Functional groups of PaSC were determined based on the peaks of spectra which detected in the absorption area of the protein wave number

\section{Results and Discussion}

\subsection{Yield and moisture content of PaSC from the skin of snake-head fish}

The yield percentage of PaSC extracted from the skin of snake-head fish was $8.9 \%$ (wet weight basis). Compared to other sources of collagen, the obtained yield of PaSC was slightly similar with pepsin soluble collagen (PSC) extracted from the skin of brown-banded bamboo shark (8.86\%) (8), but was higher than PSC from striped catfish $(7.7 \%)$ (7), brownstripe red snapper (4.7\%) (1), and bigeye snapper (1.1\%) (5). Both pepsin and papain may cause structural changes through action on intermolecular cross-links (19). Cross-linking molecule of collagen was contributed by covalent bonds through condensation of aldehyde groups at telopeptide region (1). In terms of the yield difference, the papain might have a higher collagen solubility than pepsin, which able to extract a higher collagen 
from the tissue. Besides, the higher collagen solubility in papain than other proteolytic, e.g. bromelain and Calotropis was observed for chicken, giant catfish, pork and beef (20). This indicated that this plant-origin protease could be used as an alternative enzyme to obtain optimal the extracted collagen.

The moisture content of snake-head PaSC was $6.07 \%$. The result showed that PaSC has lower moisture content than PSC from brownbanded bamboo shark skin (8.86\%) (8) and PaSC from barramundi skin (11.12\%) (9). The difference in the moisture content could be caused by a different method used. For example, in our study the hydrolysate of PaSC was freeze-dried, which was not indicated in the method by Phanat (2010) (8). The freeze-drying could reduce a higher amount of content inside the collagen

\subsection{Characterization of PaSC from the skin of snake-head fish and its molecular weight}

SDS-PAGE analysis of PaSC from snake-head fish skin is shown in Figure 1. The PaSC comprising of two $\alpha$-chains ( $\alpha-1$ and $\alpha-2$ ) was characterized as type I collagen (Figure 1 ), in which the band intensity of $\alpha-1$ is higher than $\alpha-2$. This result was in agreement that type I collagen comprised of two identical $\alpha$ - chains, $\alpha-1$ and $\alpha-2$ (21). Type I collagen was found in skin, tendons, and bones (22). The two $\alpha$ structure in fish collagen can be separated by SDS-PAGE based on their affinity to SDS, where $\alpha-2$ had a higher affinity for SDS compared to $\alpha-1$.

Molecular weight of PaSC was determined by comparing the standard protein, which molecular weight has been known, to the relative mobility value (Rf). PaSC components have high molecular weights of $\gamma^{-}, \beta-, \alpha-1$ and $\alpha-2$ components, which are $264 \mathrm{kD}, 250 \mathrm{kD}$, $139 \mathrm{kD}$ and $129 \mathrm{kD}$, respectively (Figure 1). The protein bands of PaSC from snake-head fish skin in our study show a similar pattern with the bands of PSC from other types of fish containing the $\alpha$ - and $\beta$-components having molecular weights in the range of $100-130 \mathrm{kDa}$ and 200-250 kDa, respectively. These results clearly shown thatn the $\beta$ - and $\gamma$ - band indicated the cross-linking molecule of the collagen.

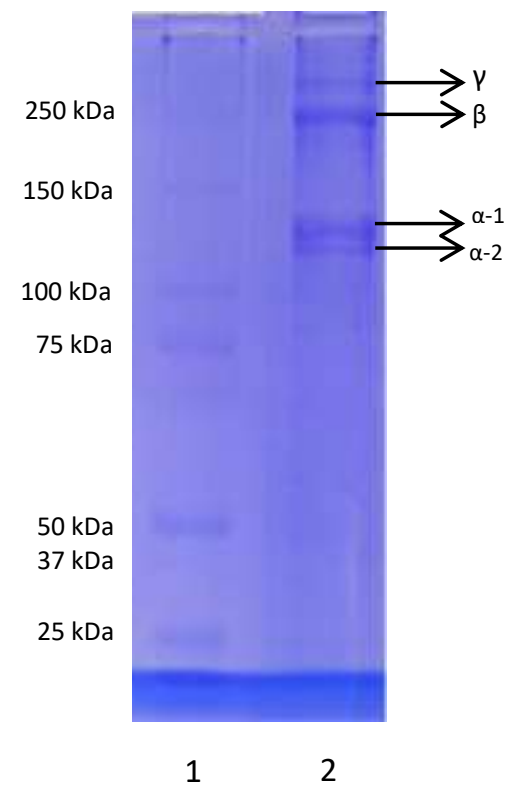

Figure 1. SDS-PAGE analysis of snake-head fish skin Papain-Soluble Collagen (PaSC), performed on 7.5 \% separation gel and 4\% stacking gel. Line 1 high molecular standards, line 2 PaSC from snake-head fish skin. SDS-PAGE 


\subsection{Functional groups of PaSC from the skin of snake-head fish}

Functional groups of PaSC from the skin of snake-head fish were depicted in the Figure 2 and Table 1. The FTIR spectra of PaSC shows a specific absorption in amide region and similar to those collagen from other species. Amide A band of PaSC was found at $3544.62 \mathrm{~cm}^{-1}$. The Amide A was characterized with vibration of $\mathrm{N}-\mathrm{H}$ stretching and generally appear at the range $3350-3550 \mathrm{~cm}^{-1}$. The change of lower range was due to the frequency of acquired absorption was shifted to the $\mathrm{NH}$ groups entangled in a hydrogen bond (23)

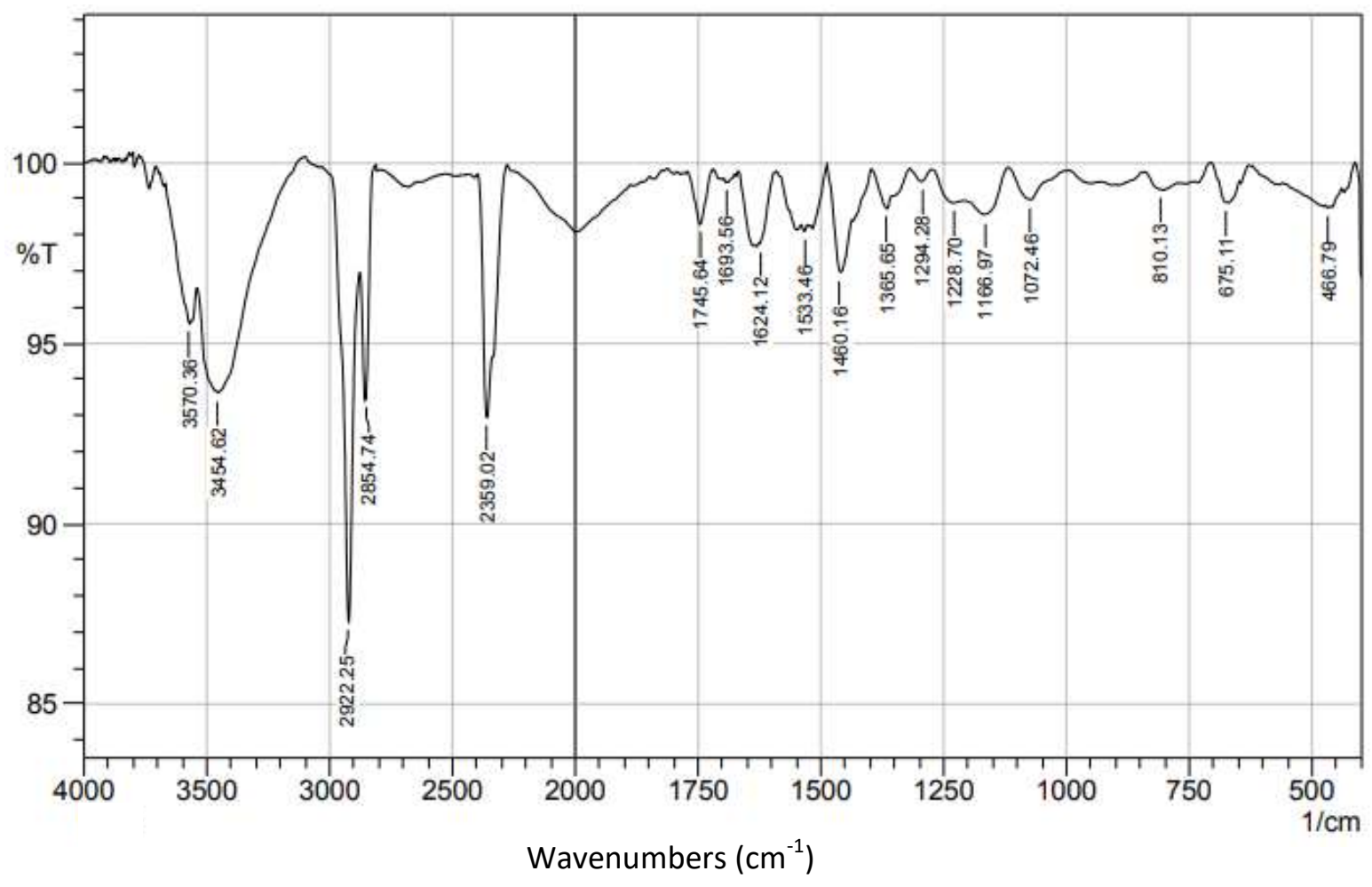

Figure 2. Fourier transform infrared (FTIR) spectrum of Papain-Soluble Collagen (PaSC) from the skin of snake-head fish

Table 1. Functional groups characteristic of Papain Soluble Collagen (PaSC) from the skin of snake-head fish

\begin{tabular}{cccc}
$\begin{array}{c}\text { Amide } \\
\text { Band }\end{array}$ & $\begin{array}{c}\text { Absorption Standard } \\
\left(\mathrm{cm}^{-1}\right)\end{array}$ & $\begin{array}{c}\text { Acquired } \\
\text { Absrption } \\
\left(\mathrm{cm}^{-1}\right)\end{array}$ & $\begin{array}{c}\text { Functional groups } \\
\text { characteristics }\end{array}$ \\
\hline Amide A & $3350-3550(24)$ & 3544.62 & $\mathrm{~N}-\mathrm{H}$ stretching (24) \\
Amide B & $2935-2915(25)$ & 2922.25 & $\begin{array}{c}\mathrm{CH}_{2} \text { asymmetric } \\
\text { stretching }(25)\end{array}$ \\
Amide I & $1600-1700(26)$ & 1624.12 & $\mathrm{C}=\mathrm{O}$ stretching (26) \\
Amide II & $1480-1575(27)$ & 1533.46 & $\begin{array}{c}\mathrm{N}-\mathrm{H} \text { Bending }(27) \\
\mathrm{CN} \text { stretching, }\end{array}$ \\
Amide III & $1229-1301(27)$ & 1294.28 & $\mathrm{NH}$ bending(27) \\
\hline
\end{tabular}

Amide $\mathrm{B}$ band of PaSC was detected at wavenumber $2922.25 \mathrm{~cm}^{-1}$ and related to vibration of $\mathrm{CH}_{2}$ asymmetric stretching. This results was an agreement with collagen that 
extracted from minke whale (28). The Amida I band was in the absorption range $1600-1700 \mathrm{~cm}^{-1}$ and associated with vibration of carbonyl group ( $\mathrm{C}=\mathrm{O}$ stretching). Amide $\mathrm{I}$, Amide II, and Amide III bands of PaSC from the skin of snake-head fish was found at wavenumber $1624.12 \mathrm{~cm}^{-1}, 1533.46 \mathrm{~cm}^{-1}$ and $1294.28 \mathrm{~cm}^{-1}$, respectively. The Amide II was characterized by $\mathrm{N}-\mathrm{H}$ Bending vibration, while Amide III was $\mathrm{CN}$ stretching and $\mathrm{NH}$ bending vibrations. The Amide III band was represent the helical structure of the PaSC with IR ratios between Aminde III and $1454 \mathrm{~cm}^{-1}$ was 1.12. The FTIR ratio that was close to 1 indicates the triple-helical structure of collagen (6).

\section{Conclusions}

In conclusion, the collagen from the skin snake-head fish skin could be extracted using the plant-based protease, papain. The PaSC was categorized as type I collagen and the FTIR ratio close to 1 shows the presence of a triple-helical structure of collagen. This results show that the snake-head fish skin can be a new potential source of the collagen and papain can be used as an alternative affordable enzyme.

\section{Acknowledgements}

This research was supported by Hasanuddin University through funding incentive of Penelitian Dosen Pemula UNHAS 2020. We thanked to all participats for their valuable contribution in this research.

\section{Author Contributions}

Andi Rahmayanti Ramli and Muhammad Dalvi Mustafa conceived and designed the experiments; Andi Rezky Annisa performed the experiments; Andi Rahmayanti Ramli analyzed the data; Andi Rahmayanti Ramli wrote first draft of the paper; Nur Alim Bahmid reviewed and edited the paper.

\section{References}

1. Jongjareonrak, A., Benjakul, S., Visessanguan, W., Nagai, T. and Tanaka. Isolation and characterisation of acid and pepsin-solubilised collagens from the skin of Brownstripe red snapper (Lutjanus vitta). Food Chem. 2005;93:475-84.

2. Shen, X. R., Kurihara, H., \& Takahashi K. Characterisation of molecular species of collagen in scallop mantle. Food Chem. 2007;102:1187-1191.

3. Fadli. Bagusnya ikan gabus [komunikasi singkat]. Warta Pasarikan. 2010;86:4-5.

4. Carvallo. Studi profil asam amino, albumin, dan mineral $\mathrm{Zn}$ pada ikan gabus dan Tomang. Universitas Brawijaya; 1998.

5. Kittiphattanabawon, P., Benjakul, S., Visessanguan, W., Nagai, T. and Tanaka M. Characterisation of acid-soluble collagen from skin and bone of bigeye snapper (Priacanthus tayenus). Food Chem. 2005;89:363-372.

6. Matmaroh K, Benjakul S, Prodpran T, Encarnacion AB, Kishimura H. Characteristics of acid soluble collagen and pepsin soluble collagen from scale of spotted golden goatfish (Parupeneus heptacanthus). Food Chem. 2011;129(3):1179-86.

7. Singh $\mathrm{P}$, Benjakul S, Maqsood S, Kishimura $\mathrm{H}$. Isolation and characterisation of collagen extracted from the skin of striped catfish (Pangasianodon hypophthalmus). Food Chem. 2011;124(1):97-105.

8. Kittiphattanabawon $P$, Benjakul S, Visessanguan W, Kishimura $H$, Shahidi F. Isolation 
and Characterisation of collagen from the skin of brownbanded bamboo shark (Chiloscyllium punctatum). Food Chem. 2010;119(4):1519-26.

9. Jamilah B, Umi Hartina MR, Mat Hashim D, Sazili AQ. Properties of collagen from barramundi (Lates calcarifer) skin. Int Food Res J. 2013;20(2):791-8.

10. Baehaki A. Kolagenase Bacillus licheniformis F11 asal Palembang dan aplikasinya pada pembuatan peptida kolagen bioaktif. Institut Pertanian Bogor; 2012.

11. Higheberger HK. Extraction of collagen. United States; 2979 438, 1961.

12. Nishihara T. Solubilization of insoluble collagen fibres and reconstitution there of. United States; 3034 852, 1962.

13. Nalinanon S, Benjakul S, Kishimura H. Characterization of collagen from the skin of unicorn leatherjacket (Aluterus monoceros) extracted with the aid of albacore tuna pepsin. KingMongkut's Agro-Industry J. 2011;3(1):53-70.

14. Zhang F, Wang A, Li Z, He S, Shao L. Preparation and Characterisation of Collagen from Freshwater Fish Scales. Food Nutr Sci. 2011;02(08):818-23.

15. Nagai T SN. Isolation of collagen from fish waste material-skin, bone and fins. Food Chem. 2000;68:277-281.

16. Rehm H. Protein biochemistry and proteomics. Elsevier: Academic press; 2006.

17. UK L. Cleavage of structural protein during the assembly of the head of bacteriophage T4. Nature. 1970;228:726-34.

18. Yan M, Li B, Zhao X. Isolation and characterization of collagen from squid (Ommastrephes bartrami) skin. J Ocean Univ China. 2008;8(2):191-6.

19. Maqsood S, Manheem K, Gani A, Abushelaibi A. Degradation of myofibrillar, sarcoplasmic and connective tissue proteins by plant proteolytic enzymes and their impact on camel meat tenderness. J Food Sci Technol. 2018;55(9):3427-38.

20. Rawdkuen S. Biochemical and microstructural characteristics of meat samples treated with different plant proteases. African J Biotechnol. 2012;11(76):14088-95.

21. Hema GS, Shyni K, Mathew S, Anandan R, Ninan G, Po M, et al. A simple method for isolation of fish skin collagen-biochemical characterization of skin collgagen extracted from Albacore Tuna (Thunnus Alalunga), Dog Shark (Scoliodon Sorrakowah), and Rohu (Labe). 2013;4(1):271-8.

22. Muyonga JH, Cole CGB DK. Characterisation of acid soluble collagen from skins of young and adult Nile perch (Lates niloticus). Food Chem. 2004;85:81-89.

23. Liu HY, Li D, Guo SD. Studies on collagen from the skin of channel catfish (Ictalurus punctaus). Food Chem. 2007;101(2):621-5.

24. Erizal, Abbas B, Setyo AK SG, Sudirman. Pengaruh iradiasi gamma pada sifat fisikokimia kolagen dalam larutan. J Sains Mater Indones. 2014;15(4):221-5.

25. Coates J. Interpretation of Infrared Spectra, A Practical Approach. Encycl Anal Chem. 2006;1-23.

26. Payne, K. J., \& Veis A. And, Fourier transform IR spectroscopy of collagen gelatin solutions: Deconvolution of the amide I band for conformational studies. Biopolymers. 1988;27:1749-1760.

27. Kong J, Yu S. Fourier transform infrared spectroscopic analysis of protein secondary structures. Acta Biochim Biophys Sin (Shanghai). 2007;39(8):549-59.

28. Nagai, T., Suzuki, N., \& Nagashima T. Collagen from common minke whale (Balaenoptera acutorostrata) unesu. Food Chem. 2008;111:296-301. 